\title{
Regulation of lonic Currents in Pheochromocytoma Cells by Nerve Growth Factor and Dexamethasone
}

\author{
Sarah S. Garber, Toshinori Hoshi, and Richard W. Aldrich \\ Department of Neurobiology, Stanford University, Stanford, California 94305
}

\begin{abstract}
Growth factors and hormones induce differentiation of clonal pheochromocytoma (PC12) cells, which are derived from rat adrenal medulla chromaffin cells. On application of nerve growth factor (NGF), PC12 cells extend neurites and express properties characteristic of autonomic ganglion cells. In contrast, incubation of PC12 cells with a corticosteroid, dexamethasone (DEX), does not induce neurite formation but causes an increase in tyrosine hydroxylase activity, suggesting that the cells become chromaffin cell-like. The ability of NGF and DEX to regulate ionic currents has been less well studied. Therefore, we examined how long-term NGF and $\mathrm{DEX}$ treatments affected voltage-dependent $\mathrm{Na}, \mathrm{Ca}$, and $\mathrm{K}$ currents in PC12 cells. Voltage-dependent $\mathrm{Na}$ currents were observed only in a small fraction of the PC12 cells in the absence of NGF or DEX. Virtually all NGF-treated cells expressed Na currents within $7 \mathrm{~d}$. DEX increased the number of cells expressing voltage-dependent $\mathrm{Na}$ current slowly over 3 weeks, but, unlike NGF, DEX did not change Na current density. Both NGF and DEX also affected the expression of voltage-dependent $\mathrm{Ca}$ currents. Most of the untreated cells had only sustained, high-threshold voltage-dependent $\mathrm{Ca}$ currents. Chronic application of NGF or DEX increased the fractions of the cells that showed transient, low-threshold T-type Ca currents in addition to the high-threshold currents. The T-type Ca current density, however, increased significantly only in NGF-treated cells. Neither DEX nor NGF affected the voltage-dependent $K$ currents. These results suggest that the expression of voltage-dependent $\mathrm{Na}$ and $\mathrm{Ca}$ currents are differentially regulated by NGF and DEX. The distinction between treated and untreated cells decreased after 3 weeks in culture as older untreated cells showed increases in the fraction of cells expressing both $\mathrm{Na}$ and low-threshold Ca currents. A PC12 subline selected for adherence to uncoated plastic also showed increased fraction of cells expressing these currents, suggesting that interactions with substrate may also influence ionic current expression.
\end{abstract}

Peptide growth factors and steroid hormones play important roles in the differentiation of excitable cells such as neurons and endocrine cells. Differentiation of excitable cells is often accom-

\footnotetext{
Received Mar. 22, 1989; revised June 1, 1989; accepted June 8, 1989.

We thank Drs. C. Bitler, R. Maue, M. P. Nusbaum, and D. Shelton for critical reading of this manuscript, Dr. R. Tsien for helpful discussion, and Drs. M. Morganfield and C. Burnett for their constant support and encouragement. We are indebted to Drs. D. L. Shelton and E. Shooter for making clone B and PC12 cell lines available to us. Supported by NS07158 to S.S.G., NIH and American Heart (CA affilate) postdoctoral fellowships to T.H., and NS23294 to R.W.A.

Correspondence should be addressed to Sarah S. Garber at the above address. Copyright (C) 1989 Society for Neuroscience $0270-6474 / 89 / 113976-12 \$ 02.00 / 0$
}

panied by changes in electrical properties (see Spitzer, 1985, for rcview). Many lines of evidence suggest that the presence of nerve growth factor (NGF) and glucocorticoids are important to the differentiation of postnatal adrenal medullary cells. Clonal PC1 2 cells, derived from rat adrenal chromaffin cells, have been used as a model system for the study of neuronal differentiation. Rat adrenal chromaffin cells and rat pheochromocytomas show similar changes in process outgrowth, catecholamine content, and tyrosine hydroxylase activity when treated with NGF or glucocorticoids (Tishler et al., 1982b, 1983).

PC1 2 cells are normally spherical in shape and do not generate action potentials. In the presence of NGF, however, the cells develop long, branching processes. This morphological differentiation is accompanied by increased synthesis and storage of ACh (Greene and Rein, 1977) and development of electrical excitability (Dichter et al., 1977), which is, in part, a result of the enhanced expression of $\mathrm{Na}^{+}$channels (Rudy et al., 1982; Mandel et al., 1988). PC12 cells have also been shown to respond to cortical steroids such as dexamethasone (DEX) by increasing the activity of tyrosine hydroxylase, an enzyme involved in the synthesis of catecholamines. Glucocorticoids, such as DEX, also inhibit neurite outgrowth (Unsicker et al., 1978; Tishler et al., 1982b). It has been suggested that NGF causes PC12 cells to develop toward autonomic neurons, whereas glucocorticoids cause them to develop toward a chromaffin cell-like phenotype (Tishler et al., 1982b, 1983). Little is known, however, about the effect of DFX on the electrophysiological properties of PC.12 cells.

Several different types of $\mathrm{Ca}^{2+}$ channels, such as $\mathrm{L}-, \mathrm{N}-$, and T-type $\mathrm{Ca}^{2+}$ channels, have been characterized (see Tsien et al., 1987 for review). High-threshold ( $\mathrm{L}$ and N) $\mathrm{Ca}^{2+}$ channels activate at relatively depolarized voltages $(>-10 \mathrm{mV})$ and can be distinguished by their slow inactivation and pharmacological properties. Low-threshold, T-type $\mathrm{Ca}^{2+}$ channels begin to activate at more hyperpolarized voltages $(<-70 \mathrm{mV})$ and inactivate rapidly with maintained depolarization. Each type of $\mathrm{Ca}^{2+}$ channel may serve a different physiological function. The distribution of the types of voltage-dependent $\mathrm{Ca}^{2+}$ channels is different among different cell types. Adrenal chromaffin cells, for example, do not express T-type $\mathrm{Ca}^{2+}$ channels, while cells from many other tissues express both T-type and L-type $\mathrm{Ca}^{2+}$ channels (Tsien et al., 1987). Both L- and N-type channels have been implicated in the control of neurotransmitter release (Rane et al., 1987; Hirning et al., 1988).

Pharmacological evidence has suggested that undifferentiated PC12 cells, like chromaffin cells, express primarily a dihydropyridine-sensitive, high-threshold voltage-dependent $\mathrm{Ca}$ current (Kongsamut and Miller, 1986). A minor dihydropyridine-insensitive $\mathrm{Ca}^{2+}$ component which increases after the ap- 
plication of NGF has also been observed (Takahashi et al., 1985; Kongsamut and Miller, 1986; Streit and Lux, 1987). These observations are consistent with the development of a neuronal phenotype in the presence of NGF.

The amount and temporal pattern of $\mathrm{Ca}$ influx can be regulated by voltage-dependent $\mathrm{Na}, \mathrm{Ca}$, and $\mathrm{K}$ channels. Because the regulation of intracellular levels of $\mathrm{Ca}^{2+}$ is important to many cellular processes, including the differentiation of excitable cells (see Kater et al., 1988, and Miller, 1988), we hypothesized that DEX or NGF would differentially affect the expression of these ion channels. Although the effects of NGF on voltage-dependent $\mathrm{Na}$ currents of $\mathrm{PCl} 2$ cells have been studied (e.g., Mandel et al., 1988), neither the effects of NGF on other ion currents nor the effects of DEX on the electrical properties of PC1 2 cells have been systematically examined. We show here that chronic incubation of PC1 2 cells with DEX and/or NGF induces distinct changes in cellular morphologies and changes in voltage-dependent $\mathrm{Na}$ and $\mathrm{Ca}$ currents, but not in voltage-dependent $\mathrm{K}$ currents.

\section{Materials and Methods}

Cell culture. $\mathrm{PC} 12$ cells were obtained from the laboratory of Dr. E. M. Shooter (Department of Neurobiology, Stanford University, CA). The cells were maintained in plastic Lux tissue culture dishes (Miles Laboratories, Naperville, IL) with Dulbecco's modified Eagle's medium with or without $25 \mathrm{~mm}$ HEPES (GIBCO, Grand Island, NY), supplemented with 5\% horse- and 5\%-supplemented calf sera (Hyclone Laboratories, Logan, UT). Two different lots of each sera type produced indistinguishable results. Levels of glucocorticoids in the media were $<30 \mathrm{~nm}$. For most of the electrophysiological experiments, the cells were plated on borosilicate glass coverslips (Bellco Biological Glassware, Vineland, NJ). The coverslips were seeded such that cells became confluent after 3-3.5 weeks. The length of time a culture was maintained was measured from the day a new plating was made. $\beta$-NGF (200 ng/ $\mathrm{ml})$ and DEX $(1 \mu \mathrm{M})$ were added at the time of the new plating and were present thereafter in the medium. The medium was changed twice per week. In some experiments, coverslips were coated with Cell-Tak (a preparation of barnacle glue shown to increase attachment of tissue culture cells: BioPolymers, Inc., Farmington, CT) or with nitrocellulose (Lagenaur and Lemmon, 1987). $\beta$-NGF was a gift from Prof. E. M. Shooter.

An adherent PC12 subclone, clone B, was obtained from Dr. D. L. Shelton (Department of Neurobiology, Stanford University, Stanford $\mathrm{CA})$ and selected from the parent PC12 stock as follows: PC12 cells were plated on Costar (Cambridge, MA) dishes. After $24 \mathrm{hr}$, medium was removed and fresh medium was vigorously and repeatedly squirted into the dish in an attempt to remove all the cells. Cells which remained adherent to the dish were then fed with fresh medium. This procedure was repeated every other day. Discrete colonies of very adherent cells were apparent after 4 weeks. These adherent colonies were then grown for 2 weeks in the presence of NGF. Colonies which were well separated and exhibited vigorous neurite outgrowth were picked individually. These clones were placed in NGF-free medium and allowed to proliferate.

Electrophysiology. $\mathrm{PC1} 2$ cells were voltage-clamped using the tightseal whole-cell patch-clamp method (Hamill et al., 1981). Electrophysiological data were collected and analyzed essentially as described previously (Hoshi and Aldrich, 1988a, b). Capacitative and leak currents have been subtracted from the data shown. All experiments were performed at room temperature $\left(20 \pm 2^{\circ} \mathrm{C}\right)$. Unless otherwise noted, the data were obtained from the cells grown on uncoated coverslips.

The following 2 methods were used to improve voltage-clamp of NGF-treated cells. (1) NGF-treated cells were grown in suspension. The cells in suspension do not extend neurites. The cells were then plated on glass coverslips 10-20 min before recording. (2) NGF-treated cells with extensive neurites were collected with a 25 gauge needle and triturated. The cells were replated on a new coverslip 10-20 min before recording. This procedure either removed or retracted the cellular processes, making the cells suitable for voltage-clamp experiments. Recordings made from cells treated in this manner represent the ionic currents primarily from the cell body. There were no marked qualitative differences in the capacitance measurements or the current recordings obtained from the cells using either of these 2 methods or those made from intact cells with neurites.

The cell capacitance was determined from the capacitative transient current in response to a $20 \mathrm{mV}$ voltage step. The whole-cell results presented are based on recordings from $>900$ cells. Single-channel recordings were made from 25 cells.

Solutions. Whole-cell Ca currents were recorded with external solutions containing (in $\mathrm{mM}$ ) $10 \mathrm{CaCl}_{2} ; 130$ tetraethylammonium (TEA); 2 $\mathrm{MgCl}_{2} ; 10$ HEPES; 5 4-aminopyridine; internal solutions contained (in mM) $120 \mathrm{CsCl} ; 20$ TEA; $2 \mathrm{MgCl}_{2} ; 11$ EGTA; $1 \mathrm{CaCl}_{2} ; 10$ HEPES; 10 nM free $\mathrm{Ca}^{2+}$. Whole-cell $\mathrm{Na}$ and $\mathrm{K}$ currents were recorded with external solutions with $140 \mathrm{NaCl} ; 2.8 \mathrm{KCl} ; 2 \mathrm{MgCl}_{2} ; 1 \mathrm{CaCl}_{2} ; 10 \mathrm{HEPES}$ (solutions contained up to $40 \mathrm{~mm}$ sucrose); internal solutions normally contained (in mM) $140 \mathrm{KCl} ; 2 \mathrm{MgCl}_{2} ; 11$ EGTA; $1 \mathrm{CaCl}_{2} ; 10$ HEPES; $10 \mathrm{nM}$ free $\mathrm{Ca}^{2+}$. All solutions were brought to $\mathrm{pH} 7.2$ with $\mathrm{N}$-methylglucamine (NMG). Single-channel recordings were made in the cellattached configuration. The pipette was filled with (in $\mathrm{mm}$ ) $105 \mathrm{BaCl}_{2}$; 10 HEPES; $\mathrm{pH} 7.2$ with TEAOH. The bath solution contained (in $\mathrm{mM}$ ) $140 \mathrm{~K}$-gluconate; $3 \mathrm{MgCl}_{2} ; 1$ EGTA; 10 HEPES; pH 7.2 with NMG Other solutions used are described in the figure legends. Salts and DEX (cell culture grade) were obtained from Sigma Chemical Co. (St. Louis, MO).

Statistical analysis. Recordings from cells were scored on the absence or presence of transient T-type $\mathrm{Ca}$ current, $\mathrm{Na}$ current, or transient $\mathrm{K}$ current. Recordings made from cells within each treatment group were distributed over $30 \mathrm{~d}$ after plating. Data from each group, at each time point, were pooled for statistical comparison. We found that changes in the numbers of cells expressing the ionic current in question and current densities occurred gradually. These changes could be summarized by pooling the data into groups which were treated up to (and inclusive of) $21 \mathrm{~d}$, over $21 \mathrm{~d}$, or up to $30 \mathrm{~d}$. Percentages of cells expressing either T-type Ca current or Na current were determined as a simple average of cells within a treatment group over an indicated time period. Differences in the fractions of the cells expressing the ion current of interest between different treatment groups were evaluated using the 2-tailed $\chi^{2}$ test. A level of $p=0.05$ was considered to be significant. Current densities were determined as an average of [peak current amplitude/cell capacitance].

\section{Results}

\section{Morphological changes induced by NGF and DEX}

Treatment of PC12 cells with NGF, DEX, or both NGF and DEX together (DEX/NGF) resulted in distinct morphological changes (Fig. 1). Untreated PC12 cells remained mostly round, with occasional oval and rare flat cells, over the course of 4 weeks in culture (Fig. $1 A$ ). DEX-treated cells became larger and more irregular in shape over $2-3$ weeks (Fig. $1 B$ ). These DEXtreated cultures did not become confluent, suggesting that cell division had been drastically slowed (Goodman et al., 1979; Schubert et al., 1980). Cultures treated with DEX for 4 weeks showed a large proportion of cells in clumps with occasional cytoplasmic degeneration (Harris et al., 1986). Isolated cells were chosen for recording in order to increase fidelity of the voltage clamp. Cells treated with NGF ceased dividing and extended long processes within 2-3 d from the beginning of the treatment (Fig. 1C). The presence of both DEX and NGF together prevented the extensive neurite outgrowth observed in the presence of NGF alone. Only short, stubby processes were observed on DEX/NGF-treated cells during the first wccks of culture (Fig. 1D). Longer, thick processes were observed on DEX/NGF-treated cells after 4 weeks in culture. These results of DEX and NGF treatment are similar to those observed in adrenal chromaffin cells (Unsicker et al., 1978; Tishler et al., 1982b; Lillien and Claude, 1985).

Changes in membrane area, as measured by cell capacitance, were also observed with NGF and DEX. The capacitance of untreated cells, ranging from 4 to $12 \mathrm{pF}$, remained stable with 

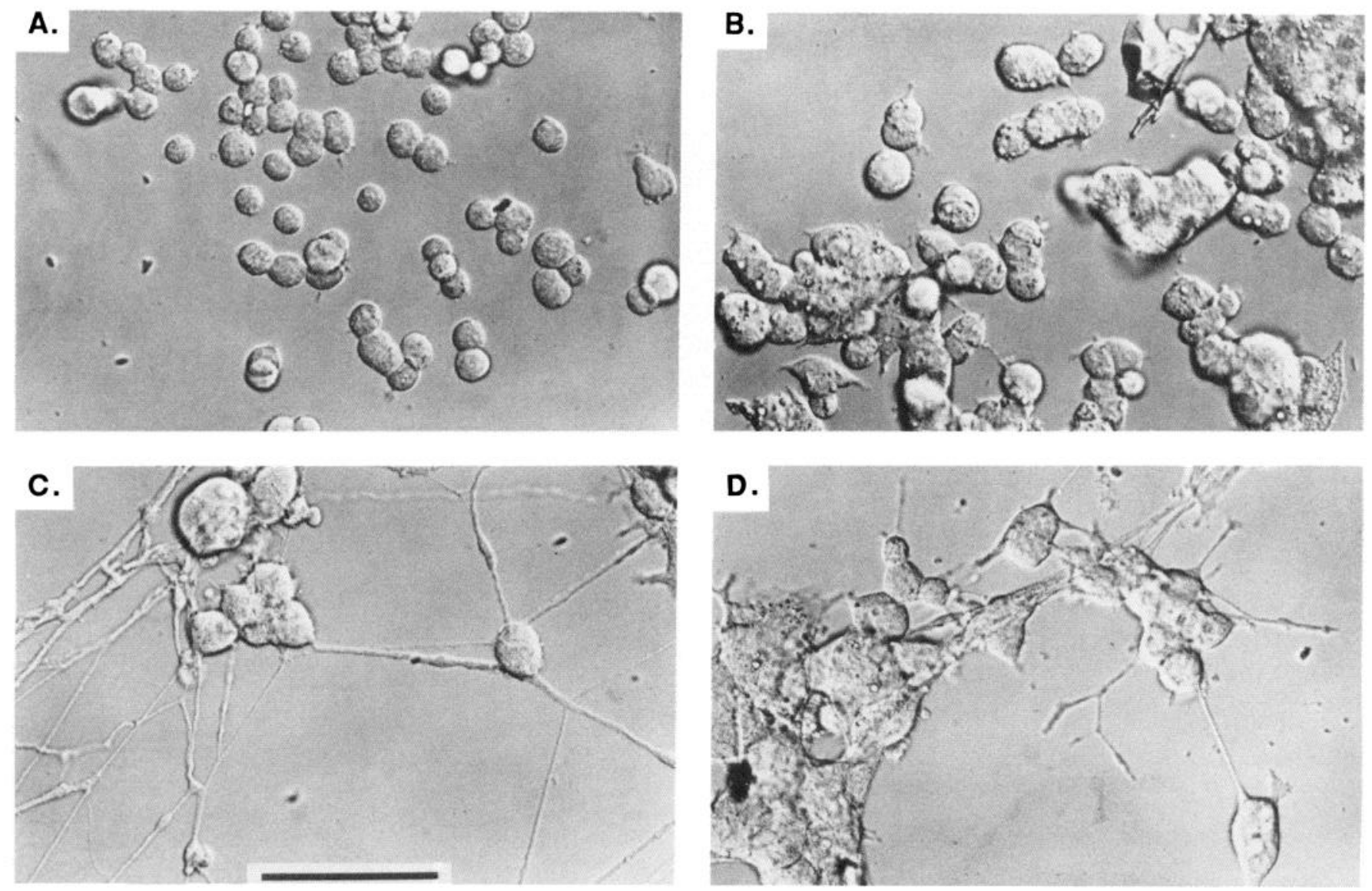

Figure 1. PC12 cells grown $(A)$ untreated (12 d) or in the presence of $(B)$ DEX (20 d), (C) NGF (12 d), and both $(D)$ DEX and NGF (12 d) have distinct morphologies. Untreated cells remain round and 15-20 $\mu \mathrm{m}$ in diameter. DEX-treated cells become larger with increased time in culture, and often appear to lose distinct cellular boundaries. The extensive neurite-like processes observed within days of the application of NGF alone appeared as short, stubby processes in the presence of DEX and NGF. Scale bar, $50 \mu \mathrm{m}$. Photographs were taken using DIC (Nomarski) optics.

time in culture (Fig. $2 A$ ). DEX, or NGF alone, however, increased the capacitance in some cells by 2 - to 3 -fold (Fig. $2 B$, C). The measured capacitance of NGF-treated cells reflects primarily that of the cell bodies because most of the neurites were sheared off for more accurate electrophysiological measurements (see Materials and Methods). The capacitance of cells treated with both DEX and NGF increased 4- to 5 -fold over that of the untreated population within the first week of treatment (Fig. 2D). It was not possible to reliably determine the capacitance of NGF- and DEX/NGF-treated cells after 2 weeks in culture because of the large size of the cells. It was also difficult to obtain high resistance seals with older NGF- and DEX/NGFtreated cells, resulting in smaller test populations for these categories. These cultures, however, remained viable for several weeks. The capacitance measurements made on DEX-, NGF-, and DEX/NGF-treated cells represent a lower estimate of the membrane area as our bias was to record currents from smaller, isolated cells in order to increase the fidelity of the voltageclamp.

\section{$D E X$ antagonizes $N G F$-induced increase in voltage-dependent Na current density}

PC12 cells without (Fig. $3 A$ ) and with (Fig. $3 B$ ) voltage-dependent $\mathrm{Na}$ currents were found in all treatment groups (untreated, DEX, NGF, and DEX/NGF). The peak current-voltage $[I(V)]$ relationships of representative currents are shown in Figure $3 C$.
Cells were scored as expressing voltage-dependent $\mathrm{Na}$ current if transient inward currents greater than $25 \mathrm{pA}$ in amplitude were recorded at $-10 \mathrm{mV}$ following a $1 \mathrm{sec}$ hyperpolarizing prepulse to a voltage $\leq-100 \mathrm{mV}$, using $\mathrm{Na}^{+}$-containing external solutions. In cells expressing Na current, little or no inward current was observed following a prepulse to $-50 \mathrm{mV}$. In a majority of the experiments, Na currents were recorded with an internal solution containing $\mathrm{K}^{+}$, resulting in the presence of voltage-dependent outward currents at voltages $\geq-10 \mathrm{mV}$. However, the outward currents activated much more slowly than the voltage-dependent $\mathrm{Na}$ currents at voltages $<0 \mathrm{mV}$ (see Fig. 3). Thus, the measurements of the peak inward currents observed at $-10 \mathrm{mV}$ were only slightly contaminated by the outward $\mathrm{K}$ currents. Because the replacement of external $\mathrm{Na}^{+}$ with $\mathrm{NMG}^{+}$almost completely abolished any inward currents observed, Ca currents contributed very little to the inward current measured with these solutions. The relative proportion of cells expressing $\mathrm{Na}$ current changed over time in response to different treatments. The properties of the voltage-dependent $\mathrm{Na}$ currents recorded from cells under different treatments, however, did not differ noticeably. The presence of the $\mathrm{Na}$ current was not correlated with any specific cellular morphology or with membrane area.

Voltage-dependent Na current was observed only in a minority of the untreated cells $(24 \%, n=39)$ over a 21 d period after plating (Fig. 4A). The number of untreated cells expressing 

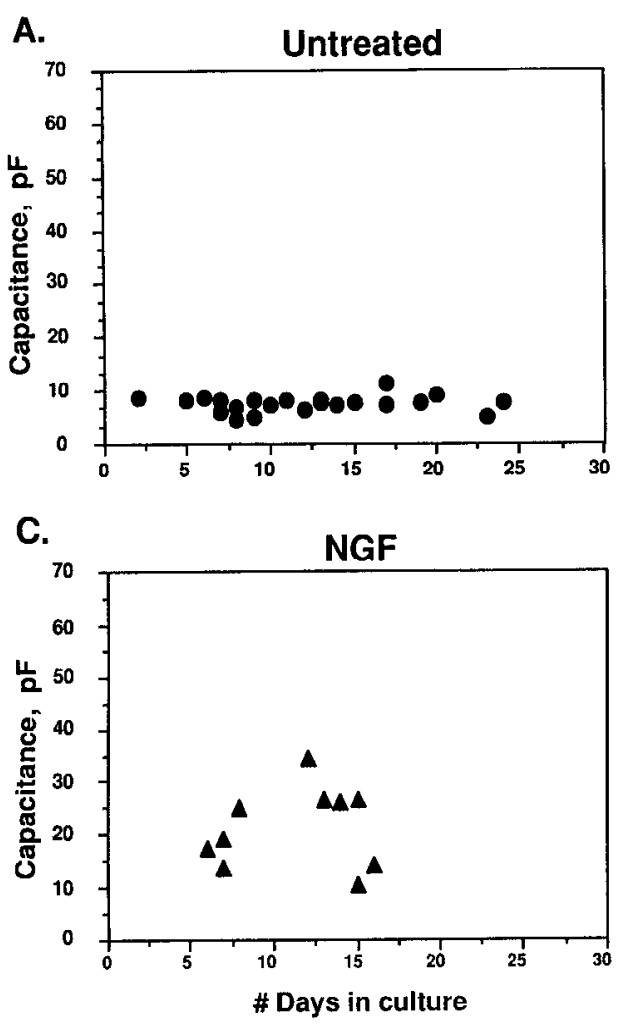

B.

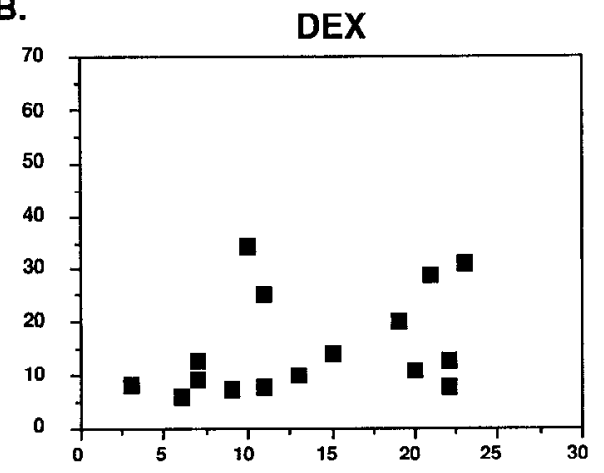

D.

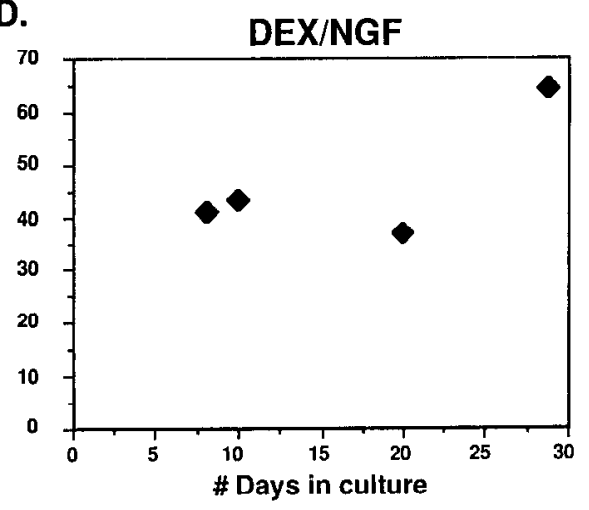

Figure 2. Capacitance of $(A)$ untreated $\mathrm{PCl} 2$ cells remained $8 \pm 4 \mathrm{pF}$ for 4 weeks. The capacitance of some cells increased up to 2- to 3-fold in the presence of $(B)$ DEX and $(C)$ NGF and 4- to 5 -fold in the presence of $(D) \mathrm{DEX} /$ NGF. Each data point shown is an avcrage capacitance of at least 3 cells. voltage-dependent $\mathrm{Na}$ current also increased with time in culture (Fig. 4A), while the current density decreased (Fig. 4B). Voltage-dependent $\mathrm{Na}$ currents were expressed in $88 \%$ of NGFtreated cells $(p=0.0001, n=33$ : Fig. $4 A$ ). The Na current density in NGF-treated cells increased 3-fold with respect to untreated cultures (Fig. 4B). Significantly more cells exhibited $\mathrm{Na}$ currents when incubated with DEX than untreated cells $(72 \%, p=0.0004, n=46$ : Fig. $4 C)$. This increase was not accompanied by an increase in $\mathrm{Na}$ current density (Fig. $4 D$ ), suggesting that, along with the increase in membrane area (Fig. $2 B)$, there is an increase in the total number of $\mathrm{Na}^{+}$channels.

Treatment with both DEX and NGF also increased the percentage of cells expressing Na current ( $p=0.005, n=5$ : Fig. $4 C)$. This increase was significant despite the small sample size. The presence of DEX, however, antagonized the increase in the Na current density induced by the presence of NGF alone. When compared with the large increase in $\mathrm{Na}$ current density in NGF alone, the increase in DEX/NGF-treated cells was only to 1.2fold over untreated cells (Fig. $4 D$ ). This antagonistic effect of DEX on current density is at least partly due to the larger increase in membrane area of these cells (Fig. 2D). No significant changes in Na current density over time in culture were observed in DEX- or DEX/NGF-treated cells.

\section{Both DEX and NGF alter voltage-dependent Ca current}

Two distinct types of voltage-dependent $\mathrm{Ca}$ current were observed in PC12 cells; sustained high-threshold Ca current and low-threshold, transient T-type $\mathrm{Ca}$ current. All whole-cell $\mathrm{Ca}$ current experiments were done under conditions in which $\mathrm{Ca}^{2+}$ was the only charge carrier. The criteria for the presence of T-type Ca current was the appearance of transient inward current, greater than $5 \mathrm{pA}$ in amplitude in response to a depolarizing pulse to $-10 \mathrm{mV}$ from a holding potential of $\leq-80 \mathrm{mV}$. Under this protocol, L-type $\mathrm{Ca}^{2+}$ channels would be activated but a proportion of $\mathrm{N}$-type $\mathrm{Ca}^{2+}$ channel were probably inactivated. We do not make a distinction between $\mathrm{L}$ and $\mathrm{N}$ Ca currents and have denoted nontransient, sustained $\mathrm{Ca}$ currents as highthreshold Ca currents. The $\mathrm{L}$ and $\mathrm{N}$ components of high-threshold $\mathrm{Ca}$ currents are difficult to separate in PC12 cells without determining dihydropyridine sensitivity (Plummer et al., 1989). In cells expressing the T-type Ca current, very little or no transient $\mathrm{Ca}$ current was observed following a $1 \mathrm{sec}$ prepulse to -40 $\mathrm{mV}$.

Untreated, DEX-, NGF-, and DEX/NGF-treated cells each fell into 2 populations: those that expressed only high-threshold $\mathrm{Ca}$ currents (Fig. $5 A$ ) and those that expressed both high-threshold and T-type currents (Fig. 5B). High-threshold currents were observed in virtually all cells examined. Peak $I(V)$ relationships (Fig. 5C) showed that high-threshold Ca current had a maximal amplitude at $+20 \mathrm{mV}$, whereas T-type Ca current had a maximal amplitude at -20 to $-10 \mathrm{mV}$ following a prepulse to -90 $\mathrm{mV}$. Representative openings of the single channels which underlie the T-type and high-threshold Ca currents are shown in Figure 6. In agreement with the properties of the whole-cell $\mathrm{Ca}$ currents, the probability of the T-type channel being open rapidly increased after a depolarization to $-20 \mathrm{mV}$ and then declined rapidly (Fig. $6 A$ ). In contrast, the probability of a single high-threshold-type channel being open did not decline noticeably during a pulse to $0 \mathrm{mV}$ (Fig. $6 B$ ). The amplitude and gating properties suggest that these records are from an L-type channel. We did not, however, confirm this by testing dihydropyridine sensitivity. The unitary current amplitude of the T-type channel was 2-3 times smaller than that of the high-threshold channel in the range of -20 to $0 \mathrm{mV}$. The mean open duration of the T-type channel was, however, markedly greater than that of the high-threshold single channel. Both T-type and high-threshold 
A.
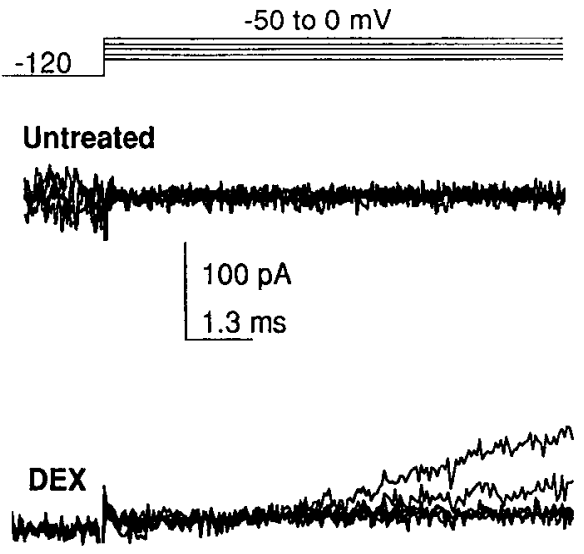

$100 \mathrm{pA}$

$1.3 \mathrm{~ms}$

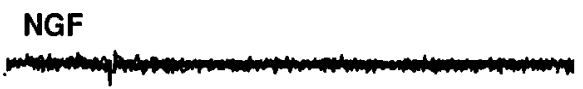

$400 \mathrm{pA}$

$1.3 \mathrm{~ms}$

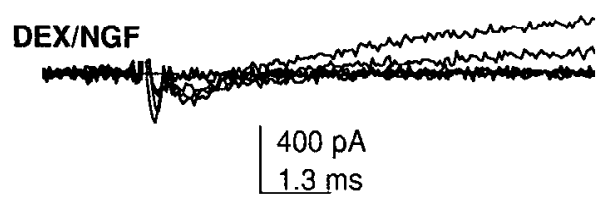

B.
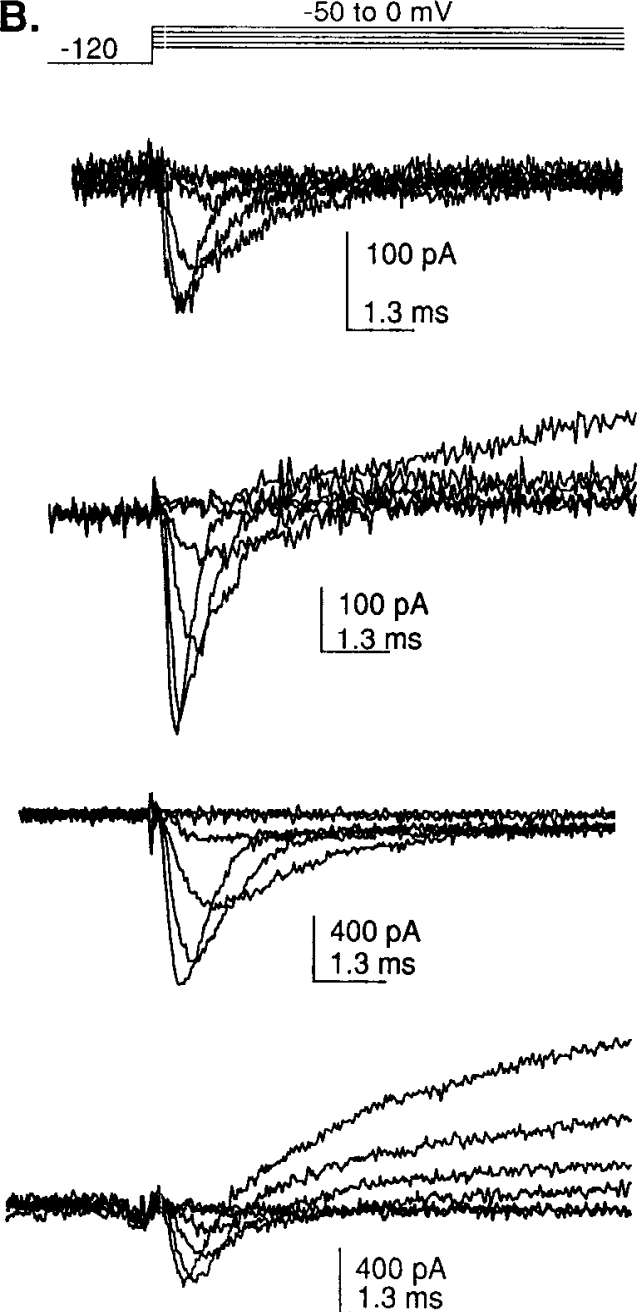

C.

Without $\mathrm{Na}$ + current With $\mathrm{Na}+$ current
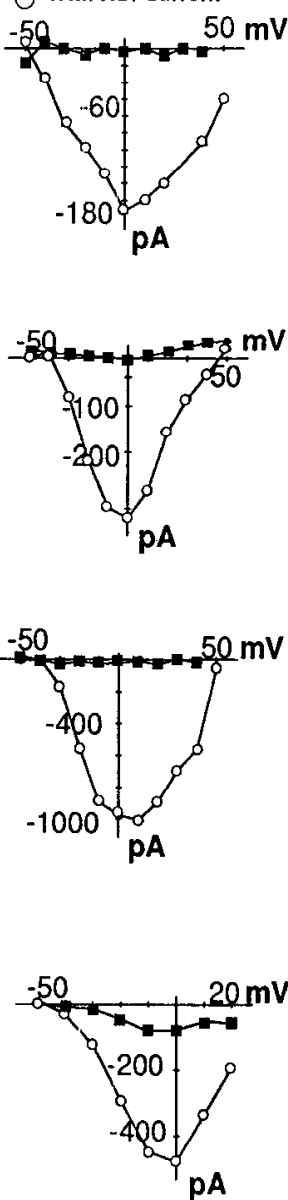

Figure 3. Representative families of the voltage-dependent Na currents from untreated, DEX-, NGF-, and DEX/NGF-treated cells. In each treatment group, some cells $(A)$ expressed no or little $\mathrm{Na}$ current and others $(B)$ expressed appreciable amounts of Na current. The currents were elicited at the voltages shown following $1 \mathrm{sec}$ prepulses to voltages $\leq-100 \mathrm{mV}$. $C$, Peak $I(V)$ curves were obtained from cells which did not express the Na current (black squares) and those which expressed the Na current (circles). The voltage-dependent Na currents were often recorded using an internal solution containing $\mathrm{K}^{+}$, thus resulting in outward voltage-dependent $\mathrm{K}$ currents at positive voltages. However, the voltage-dependent $\mathrm{K}$ currents activated much more slowly than the voltage-dependent Na current at the voltages more negative than $+10 \mathrm{mV}$ (see DEX records in $A$ ). In other experiments (untreated and NGF records in $A$ and $B$ ), outward $\mathrm{K}$ currents were reduced substantially by using an internal solution with $\mathrm{Cs}^{+}$(see Materials and Methods). Some fidelity of the voltage-clamp in DEX/NGF cells was lost because of the very large cell size (see Fig. $2 D$ ). The apparent inward currents observed in DEX/NGF cells in $A$ were artifacts of the imperfect leak current subtraction [see the corresponding $I(V)$ curve in $C$ ].

currents observed in this study closely resemble those described in other preparations (Tsien et al., 1987). Plummer et al. (1989) have also described single, high-threshold $\mathrm{L}$ and $\mathrm{N} \mathrm{Ca}^{2+}$ channels in PC1 2 cells.

The relative proportion of cells expressing T-type current changed in response to the length of time cells were treated with DEX, NGF, or DEX/NGF. Only $20 \%$ of untreated cells $(n=$ 101), grown in culturc up to 3 wecks, cxpressed the T-type current in addition to the high-threshold current (Fig. $7 A$ ). In the presence of DEX, the fraction of cells expressing T-type Ca currents increased slowly over the course of 3 weeks to $40 \%$ ( $p$ $=0.0008, n=142$; Fig. $7 A$ ). There was a small increase in T-type current densities with the DEX treatment (Fig. $8 B$ ). Ca current densities did not change with time in DEX-treated cells. Treatment with NGF alone increased the fraction of cells expressing the T-type current within $7-10 \mathrm{~d}$ to $\sim 60 \%(p=0.017$, $n=44:$ Fig. $7 A$ ) and resulted in a 3 -fold increase in the density of T-type current with respect to untreated cells (Fig. 8C). NGF treatment did not markedly change the high-threshold Ca curreni density. High-threshold currents were assayed as previously described. Under these conditions, not all the $\mathrm{N}$ channels may be available for opening. These experiments would not detect changes in current density of high-threshold channels which may require longer times to recover from inactivation. The presence of the T-type voltage-dependent Ca current in any of the treatment groups was not correlated with any specific cellular morphology or with cell capacitance. Voltage-dependence of T-type and high-threshold $\mathrm{Ca}$ currents did not differ markedly among treatment groups.

Despite the ability of either DEX or NGF to increase the fraction of cells expressing T-type Ca current, the percentage of DEX/NGF-treated cells with T-type Ca current was not signif- 
A.

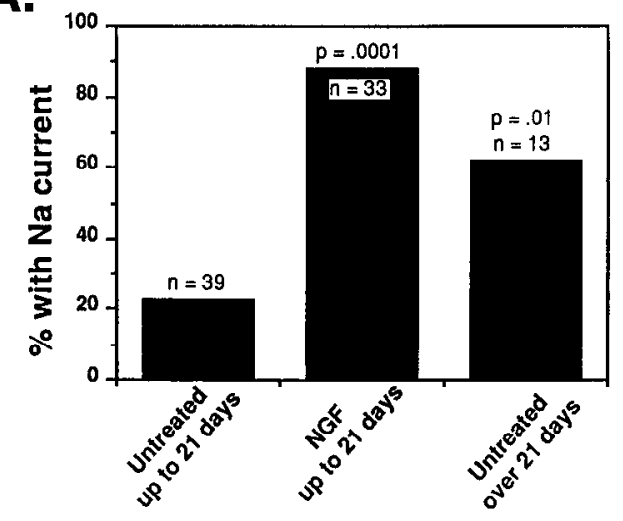

C.

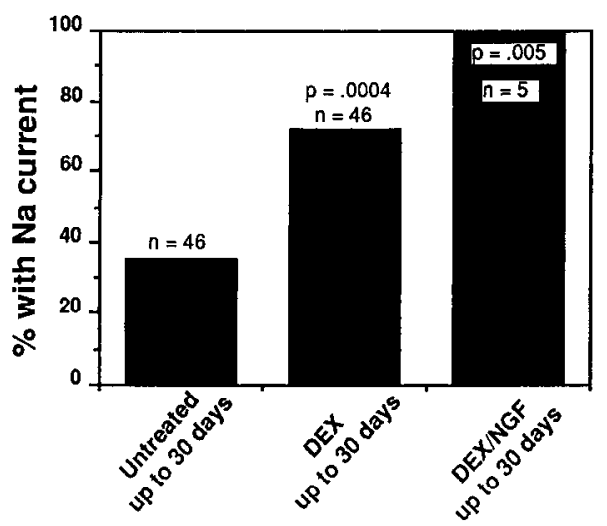

B.

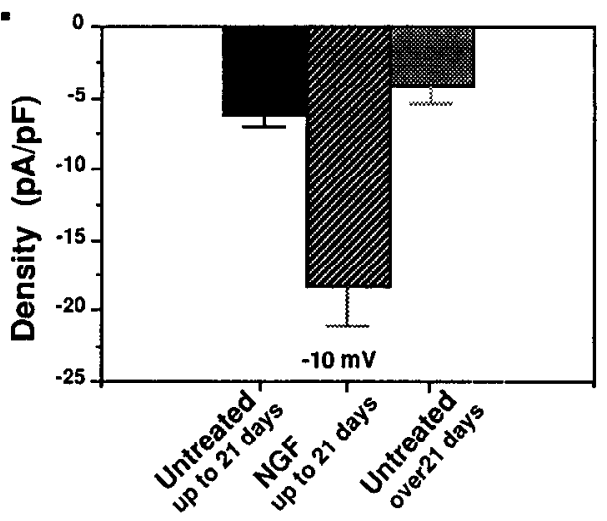

D.

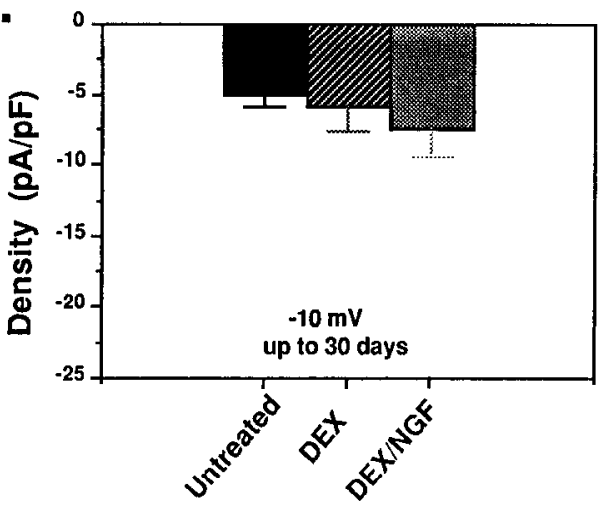

Figure 4. $A$, The fraction of untreated control cells expressing Na current grown in culture less than $21 \mathrm{~d}$ compared to NGF-treated cells and untreated cultures grown for over $21 \mathrm{~d}$. $B$, Average densities of the voltage-dependent Na current in untreated cells grown for less than $21 \mathrm{~d}$ in culture compared to NGF-treated cells and untreated cells grown for more than $21 \mathrm{~d}$ in culture. $C$, DEX-and DEX/NGF-treated cells compared to untreated populations grown over $30 \mathrm{~d}$ in culture. No significant differences were observed between DEX- and DEX/NGF-treated cells grown up to and over $21 \mathrm{~d}$ in culture; thus, these populations were pooled for each treatment. $D$, Na current density of DEX-and DEX/NGF-treated cells compared to that of untreated cells grown in culture over a $30 \mathrm{~d}$ period. The total number of cells recorded in each group is given as $n$. Significant differences between untreated groups and treatment groups are given as $p$ and were determined using $\chi^{2}$ analysis. Average current density at $-10 \mathrm{mV}$ is unlikely to be contaminated by the voltage-dependent outward currents. SEM are shown as error bars.

icantly different from the control level of untreated cells over the same time period ( $p=0.35, n=19$ : Fig. $7 B$ ). The presence of DEX prevented the increase in T-type current density observed in the presence of NGF alone (Fig. $8 D$ ).

\section{T-type Ca current density increases in confluent untreated cultures}

As untreated cells became confluent after 3 weeks in culture, the fraction of the cells expressing T-type Ca current increased to $60 \%(p=0.001, n=34$ : Fig. $7 A$ ), compared with $20 \%$ found in the $0-21 \mathrm{~d}$ untreated cells. This increase is accompanied by an increase in the T-type current density in untreated cells cultured over $21 \mathrm{~d}$ (Fig. $8 A$ ). The percentage of untreated cells grown in culture for more than $21 \mathrm{~d}$ expressing T-type Ca current surpassed the level achieved by DEX treatment after 3 weeks and approached that induced by NGF over a shorter time period (Fig. 7C). Because of this increase in T-type current in $>21 \mathrm{~d}$ untreated cells, there was no significant difference in the fraction of cells with T-type Ca current between the $>21 \mathrm{~d}$ untreated cells and DEX-treated cells over $21 \mathrm{~d}(p=0.75, n=45$ : Fig. 7C). The density of T-type Ca current of the over $21 \mathrm{~d}$ untreated control cells decreased slightly with respect to DEX-treated cells recorded from up to 3 weeks in culture, while that of highthreshold current increased (Fig. 8E).

\section{Effect of substrate on T-type Ca current density}

Recent reports have suggested that cellular functions such as neurite outgrowth in cultured cells are substrate-dependent (Lin and Levitan, 1988; Tomaselli et al., 1986). Bethea and Kozak $(1984,1985)$ have also shown that PC12 cells grown in the presence of extracellular matrix release more and store less dopamine then cells grown on plastic. Although coverslips in the present experiments were uncoated borosilicate glass, confluent PC12 cells are in contact with neighboring cells. This contact may provide a substrate quite different from that encountered by a PC1 2 cell, freshly seeded at low density. Cell-cell and ccll/ extracellular matrix interactions, for example, have resulted in modulation of the NGF response in PC12 cells (Doherty et al., 1987). We therefore considered the possibility that interaction with a more adherent, nonspecific substrate was responsible for the change in the fraction of cells expressing T-type Ca current between untreated cells grown less than $21 \mathrm{~d}$ and over $21 \mathrm{~d}$ in culture.

Cells grown on glass coverslips coated with Cell-Tak to pro- 
A.
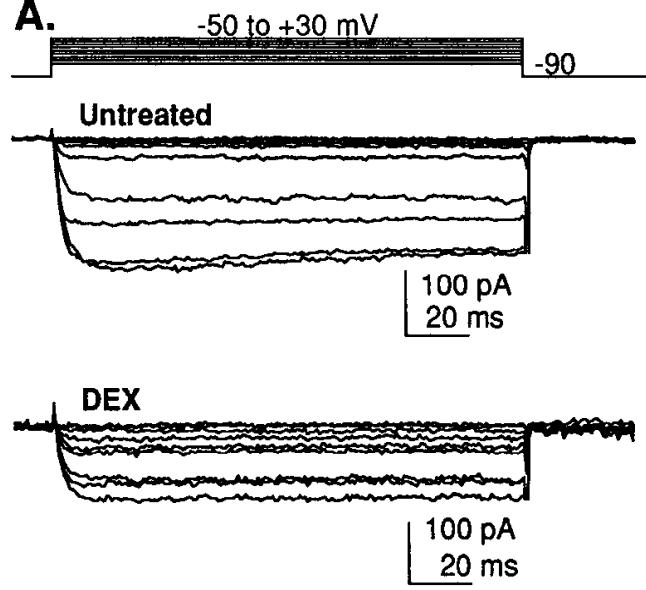

NGF

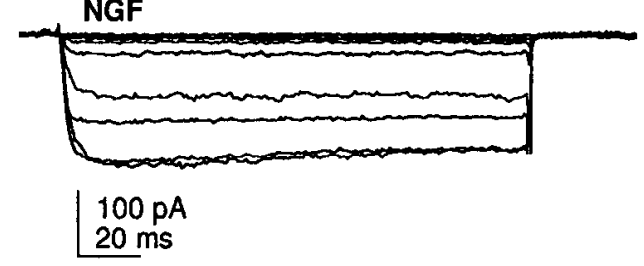

DEX/NGF

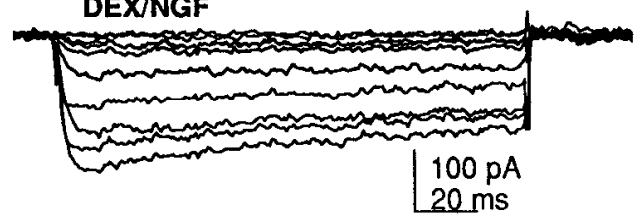

B.
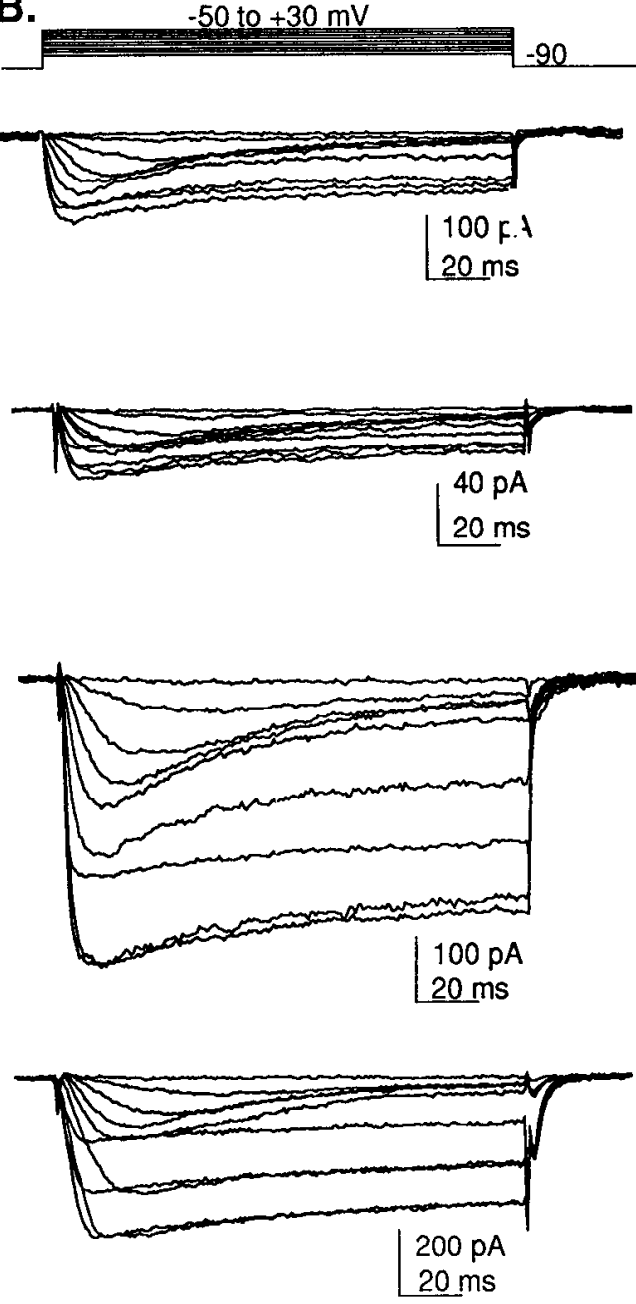
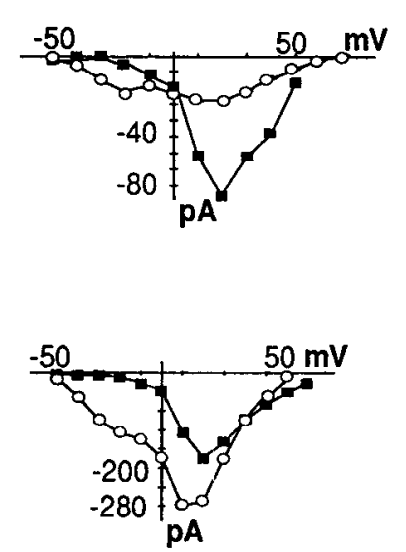

C. Without "T-Type" current
0 With "T-Type" current
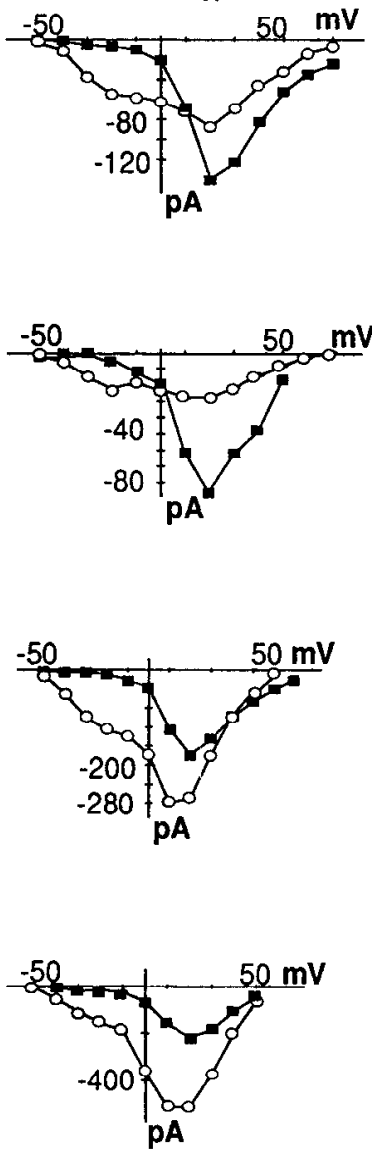

Figure 5. Representative families of Ca currents recorded from untreated and DEX-, NGF-, and DEX/NGF-treated cells. In each treatment group, some cells $(A)$ expressed only high-threshold Ca current and others $(B)$ expressed both high-threshold and T-type current. The currents shown were elicited at the voltages indicated from a holding potential of $-90 \mathrm{mV}$ (repetition interval $=6 \mathrm{sec}$ ). $C$. Peak $I(V)$ curves obtained from the cells which showed only the high-threshold current (black squares) and those which had both T-type and high-threshold currents (circles). The T-type $\mathrm{Ca}$ current shows up as a distinct shoulder at voltages more negative than $0 \mathrm{mV}$, with peak current occurring at -20 to $-10 \mathrm{mV}$. In cells expressing T-type $\mathrm{Ca}$ current, high-threshold $\mathrm{Ca}$ current was also observed. Holding potentials of $\leq-80 \mathrm{mV}$ and 1 sec prepulses to $-40 \mathrm{mV}$ elicited similar high-threshold currents. Some variability of the inactivation kinetics (independent of holding or prepulse potential) of low- and high-threshold currents was observed.

mote cellular adhesion to coverslips did not show a significant difference in the fraction of the cells expressing $\mathrm{T}$-type Ca current $(p=0.35, n=16:$ Fig. $9 A)$, although those grown on nitrocellulose did ( $p=0.02, n=12$ : Fig. $9 A)$. T-type Ca current density also did not change significantly in cells grown on Cell-Tak (Fig. $9 B$ ), but did increase in cells grown on nitrocellulose (Fig. 9C), when compared with untreated cells grown on uncoated coverslips. There was also a significant decrease in high-threshold current density in cells grown on nitrocellulose (Fig. 9C). Untreated, NGF-, and DEX-treated populations of cells grown in suspension did not alter the expression of the T-type Ca current compared with cultures grown on coverslips under equivalent conditions (data not shown).

To test the possibility that changes in the adherent properties of PC12 cells may also result in a corresponding change in ionic currents, we made recordings from a subcloned continuous, adherent PC12 cell line, clone B. Clone B was selected on the basis of its adherent properties to uncoated Costar culture dish- es. These cells were generally ovoid and slightly flat in appearance. Capacitance of clone $B$ cells was similar to that of untreated cells (data not shown). A significant fraction (77\%) of these cells expressed T-type current as compared with untreated cells grown up to $21 \mathrm{~d}$ in culture $(p=0.0001, n=31$ : Fig. $9 A)$. Other equally adherent subcloned lines also exhibited a larger fraction of cells with T-type current (data not shown). The T-current density also increased, whereas the high-threshold current density decreased, with respect to untreated populations (Fig. 9D).

Plating on Cell-Tak-coated coverslips did not result in a significant increase in percentage of cells with Na current $(p=0.28$, $n=16$ : Fig. 10A). Na current density of cells grown on CellTak did not increase significantly (Fig. 10B). The fraction of clone B cells expressing $\mathrm{Na}$ current, however, was significantly greater than untreated cells $(p=0.002, n=17$ : Fig. 10A). This was accompanied by a large increase in $\mathrm{Na}$ current density (Fig. $10 B)$. These observations suggest that the expression of adhesion molecules and the development of certain ionic currents may 
A.
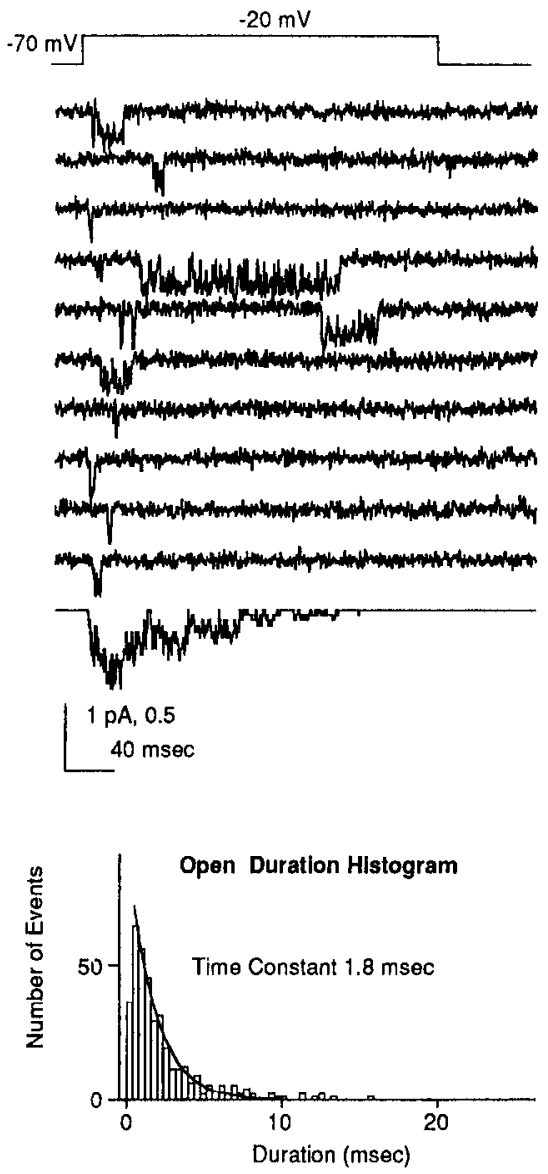

B.


Figure 6. Activity of single voltagedependent $\mathrm{Ca}^{2+}$ channels recorded from NGF-treated cells using the cell-attached recording configuration. $A$, Representative openings of the T-type $\mathrm{Ca}^{2+}$ channels elicited at $-20 \mathrm{mV}$ from a holding voltage of $-70 \mathrm{mV}$. The bottom trace is an ensemble average of idealized records showing the time course of the probability of the channel being open. The data were filtered at $500 \mathrm{~Hz}$ through an 8-pole Bessel filter and digitized at $5 \mathrm{kHz}$. Pulses were applied every $5 \mathrm{sec}$. The recording was made from the cell body. The neurites of this cell were intact. Open duration histograms of a T-type Ca channel recorded at $-20 \mathrm{mV}$ are shown below traces. $B$, Representative openings of a high-threshold $\mathrm{Ca}$ channel elicited at 0 $\mathrm{mV}$ from a holding voltage of $-40 \mathrm{mV}$. The bottom trace is an ensemble average of idealized records showing the time course of the probability of the channel being open. The recordings shown are probably from an L-type $\mathrm{Ca}^{2+}$ channel. The data were filtered at $1.2 \mathrm{kHz}$ and digitized at $10 \mathrm{kHz}$. The recording was made from the cell body. The neurites of this cell were intact. Open durations of the high-threshold Ca channcls shown below current traces were recorded at $0 \mathrm{mV}$. be linked in PC12 cells. Other processes, such as increases in acetylcholinesterase activity in PC12 cells (Lucas et al., 1980; Reiger et al., 1980) and survival of rat chromaffin cells in the presence of DEX (Grothe et al., 1985), have also been shown to be dependent on substrate.

\section{Voltage-dependent $K$ currents were not affected by NGF or $D E X$}

The whole-cell voltage-dependent K currents in the PC12 cells used in this study activate rapidly and inactivate very slowly, with transient $\mathrm{K}$ currents very infrequently observed (Hoshi and Aldrich, 1988a). DEX or NGF treatment up to 4 weeks did not increase the appearance of transient voltage-dependent $\mathrm{K}$ currents at $+10 \mathrm{mV}(p=0.088, n=66$ and $p=0.75, n=24$, respectively) or otherwise alter the composition of the wholecell $\mathrm{K}$ current. Clone $\mathrm{B}$ cells or cells grown on Cell-Tak or nitrocellulose did not show any marked differences in $\mathrm{K}$ currents. The following treatments also failed to affect these $K$ currents; dibutryl cAMP and theophylline $(2$ and $5 \mathrm{mM}$, respectively, for $2 \mathrm{~d}, p=0.99, n=5), \beta$-estradiol $(0.4 \mu \mathrm{M}$ for 3 $\mathrm{d}, p=0.29, n=9$ ), absence of sera in the medium (for $6 \mathrm{~d}, p$ $=0.47, n=2$ ).

\section{Discussion}

Both DEX and NGF have distinct effects on the morphology and complement of voltage-dependent ionic currents in PC12 cells. In general, DEX also appears to antagonize the effects of NGF. Ionic current composition, however, can also be altered to some extent by the time in culture, substrate, and perhaps by adhesion. The results described in this report are summarized below.

\section{Morphology}

Treatment with NGF alone, DEX alone, or both NGF and DEX together, increases the capacitance, and hence the membrane area, of PC12 cells. However, the extensive neurite outgrowth observed with NGF is antagonized by DEX.

\section{Voltage-dependent Na currents}

Both NGF and DEX increase the fraction of cells which express voltage-dependent Na current. Only NGF, however, causes significant increases in the Na current density. The effect of NGF on the Na current is attenuated in the presence of DEX. Both clone B, a subcloned line selected for adherence to uncoated plastic, and confluent untreated cells showed increases in the fraction of cells expressing $\mathrm{Na}$ current.

\section{Voltage-dependent Ca currents}

Chronic application of DEX or NGF or confluency of untreated cells increases the occurrence and density of T-type Ca current. Clone B cells also show increased occurrence and density of T-type Ca current in the absence of either DEX or NGF. Expression of T-type Ca current may be influenced by certain substrates. A possibly related result is that fibroblasts, which become much less adherent after oncogenic transformation, also lack T-current after tranformation (Chen et al., 1988). 
A.

B.
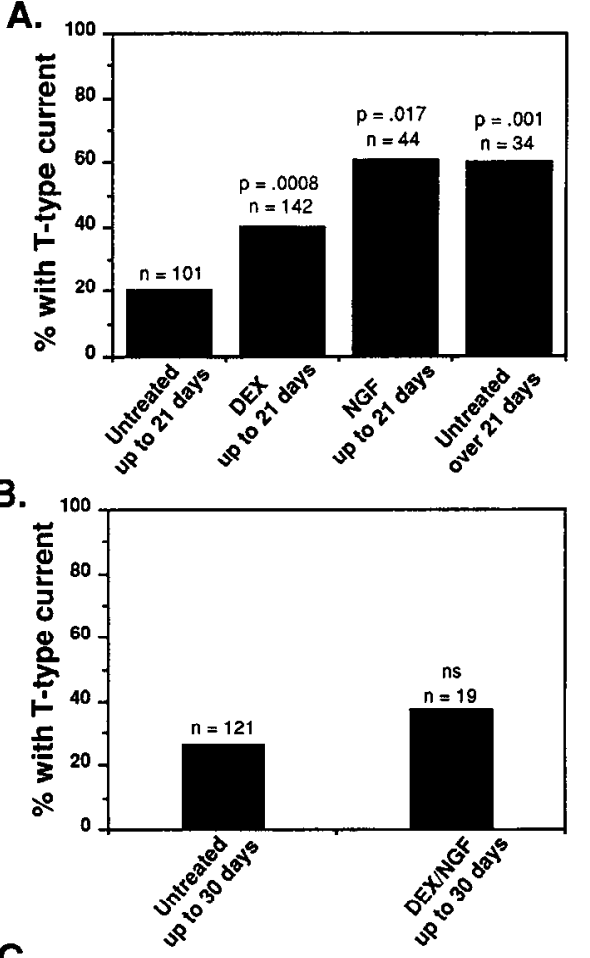

C.

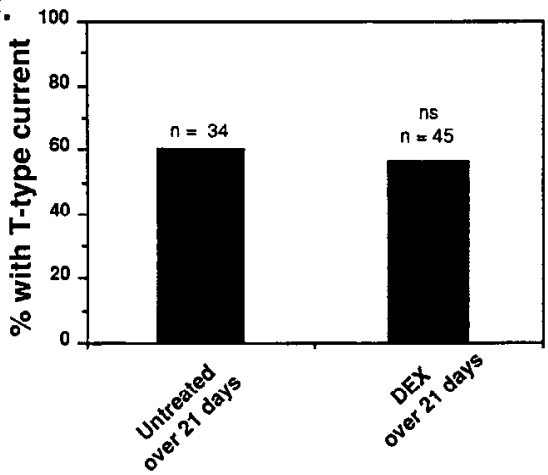

Figure 7. Percentages of cells with different treatments expressing T-type Ca current. $A$, The fraction of untreated control cells grown in culture less than $21 \mathrm{~d}$ compared to DEX-and NGF-treated cells and untreated cultures grown for over $21 \mathrm{~d}$. $B$, DEX/NGF-treated cells compared to untreated populations grown over $30 \mathrm{~d}$ in culture. $C$, Untreated cells grown in culture over $21 \mathrm{~d}$ compared to DEX-treated cells also grown over $21 \mathrm{~d}$. The total number of cells recorded in each group is given as $n$. Significant differences between untrcatcd groups (presented on the left side of each graph) and treatment groups are given as $p$ and were determined using $\chi^{2}$ analysis. $n s$ denotes $p>0.05$.

\section{Voltage-dependent $K$ currents}

Neither NGF or DEX markedly affect voltage-dependent K currents. These results are in contrast to those of Rudy and Pollock (1988), who observed that application of NGF to PC12 cells cause a decrease in a TEA-sensitive, transient voltagedependent $\mathrm{K}$ current.

The straightforward interpretation of the observed increases in the fractions of cells expressing $\mathrm{T}$-type $\mathrm{Ca}$ current or $\mathrm{Na}$ current in response to DEX and/or NGF is that there is an increase in the number of functional ion channel molecules underlying these currents. The increase in capacitance without decreases in current density suggests that new ion channel proteins are either inserted into the plasma membrane or that pre-
A.
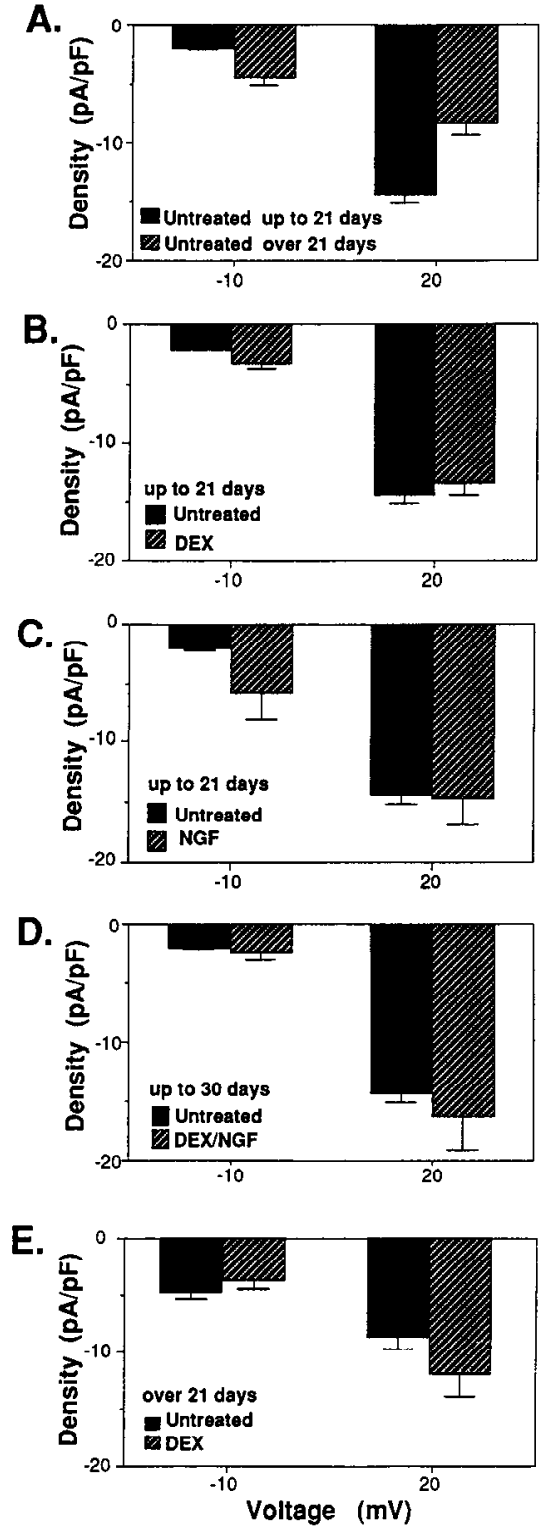

Figure 8. A, Average densities of the voltage-dependent Ca current in untreated cells grown for less than $21 \mathrm{~d}$ in culture compared to those grown for more than $21 \mathrm{~d}$ in culture. Ca current density of $(B)$ DEXand $(C)$ NGF-treated cells compared to that of untreated cells grown in culture for $<21 \mathrm{~d}$. $D, \mathrm{DEX} / \mathrm{NGF}$-treated cells compared to untrcatcd cells grown over $30 \mathrm{~d}$. $E$, DEX-treated cells grown in culture over $21 \mathrm{~d}$ compared with untreated cells of the same age. The average current density at $-10 \mathrm{mV}$ primarily represents the T-type Ca current density, while that at $+20 \mathrm{mV}$ consists primarily of the high-threshold $\mathrm{Ca}$ current density. SEM are shown as error bars.

viously inserted, but nonfunctional, channels are somehow activated. Alternatively, because a small fraction of nonconfluent, untreated cells also express $\mathrm{T}$-type $\mathrm{Ca}$ currents and $\mathrm{Na}$ currents, it is possible that treatment with DEX and/or NGF selectively enhances the division of cells containing these channels. This latter hypothesis is unlikely, however, because PC12 cells cease to divide or divide only very slowly in the presence of NGF and DEX (Greene and Tishler, 1976; Goodman et al., 1979; Schubert et al., 1980). It is possible that with an increase in confluence or age of cells, the numbers of dead or floating cells increased, resulting in an unintended selection of more adherent 
A.

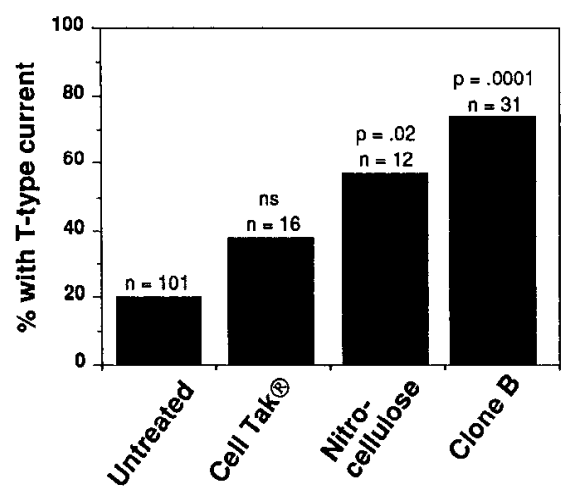

B.

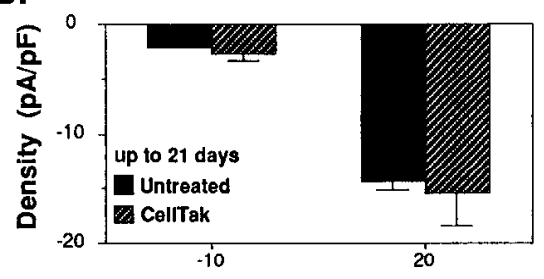

C.

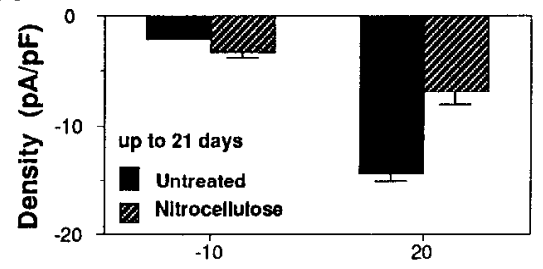

D.

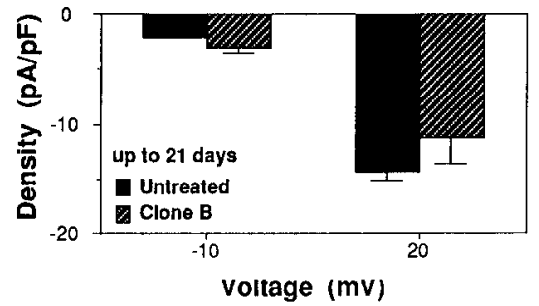

Figure 9. A, Percentages of clone B, Cell-Tak, and nitrocellulose-treated cultures expressing T-type Ca current compared with untreated cultures grown up to $21 \mathrm{~d}$ in culture. Average densities of the voltage-dependent $\mathrm{Ca}$ currents of untreated cells compared to $(B)$ CellTak- and $(C)$ nitrocellulose-treated cultures and to $(D)$ clone $\mathrm{B}$. The average current density at $-10 \mathrm{mV}$ primarily represents the T-type $\mathrm{Ca}$ current density, while that at $+20 \mathrm{mV}$ consists primarily of the high-threshold Ca current density. All test groups are compared with control cells grown on untreated borosilicate glass coverslips. The total number of cells recorded in each group is given as $n$. $n s$ denotes $p>0.05$. SEM are shown as error bars. cells with characteristics similar to that of clone B. If this were the case, however, continued passaging of $\mathrm{PCl} 2$ cells over several months should result in cell lines with greatly increased appearance of T-type $\mathrm{Ca}$ current. This is not observed (unpublished results). Another possibility is that channels are synthesized at a constant rate, and are maintained at a constant turnover rate. Thus, channels would accumulate in slowly dividing or nondividing cells (such as NGF-, DEX-treated, or confluent control cells). Mandel et al. (1988) have shown that NGF selectively induces type II $\mathrm{Na}$ channel mRNA expression and that this induction results in an increase in voltage-dependent $\mathrm{Na}$ current density. This observation suggests that, at least in the case of NGF-treated PC1 2 cells, the increase in Na current density is in part due to increased synthesis of the channel protein. We suggest that the DEX-and NGF-induced increases in the fractions of the cells with T-type Ca currents and voltagedependent $\mathrm{Na}$ currents reflect an increase in the number of active ion channel proteins in the cell membrane.
Capacitance measurements indicate that the average membrane area of the DEX- or NGF-treated PC12 cell bodies increased 2- to 3-fold. These observations suggest that both treatments result in the addition of membrane to the cell body. In the case of NGF, additional membrane may be needed for neurite extension. The increased membrane area in DFX-treated cells may be a result of membrane incorporation due to fusion of vesicles associated with the release of neurohormones. The larger increase in the capacitance of DEX/NGF-treated cells suggests that while DEX inhibits NGF-mediated neurite outgrowth, the additional membrane intended for outgrowth is still produced and is instead added to the cell body.

Previous studies have documented differential, often antagonistic, effects of DEX and NGF on cellular functions. For example, the intracellular content of neuropeptide Y (NPY) in PC1 2 cells increases in the presence of NGF but not DEX (Allen et al., 1984). Addition of DEX to NGF-treated cultures of PC12 cells prevents any further increase in NPY content (Allen et
A.

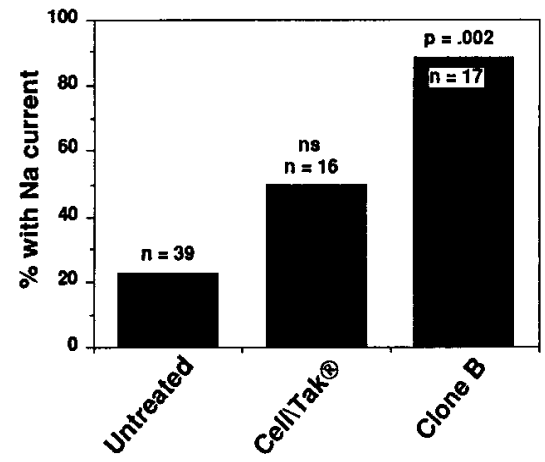

B.

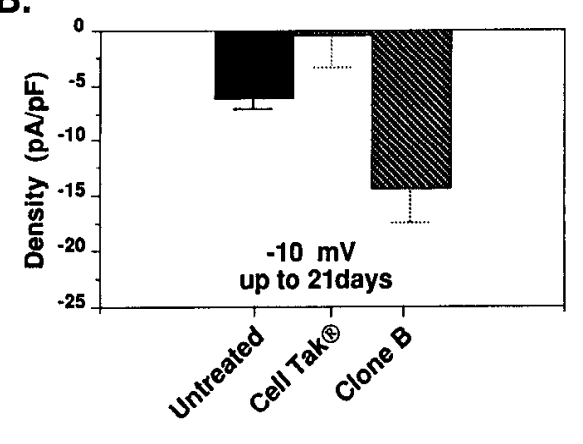

Figure 10. A, Percentages of clone B and Cell-Tak-treated cultures expressing $\mathrm{Na}$ current compared with untreated cultures grown up to $21 \mathrm{~d}$ in culture. $B$, Voltage-dependent Na current average density of untreated cells compared to clone B and Cell-Tak-treated cultures. Average current densities at $-10 \mathrm{mV}$ are shown. All test groups are compared with control cells grown on untreated borosilicate glass coverslips. The total number of cells recorded in each group is given as $n$. $n s$ denotes $p$ $>0.05$. SEM are shown as error bars. 
al., 1984). Similar observations were made concerning neurotensin and vasoactive intestinal peptide-like immunoreactivity in primary human pheochromocytoma cultures incubated with NGF or DEX/NGF (Tishler et al., 1982a, 1984, 1986). In addition, the specific activity of choline acetyltransferase increases in NGF-treated cells, whereas the specific activity of tyrosine hydroxylase increases in the presence of glucocorticoids (Greene and Rein, 1977; Edgar and Thoenen, 1978; Otten and Towbin, 1980; Schubert et al., 1980; Tishler et al., 1983). The activity of both of these enzymes, however, also increases with increased cell density (Greene and Rein, 1977; Edgar and Thoenen, 1978; Lucas et al., 1979). It is not clear whether the changes in voltagedependent ionic currents reported here and changes in enzymatic activity are associated or simply concurrent. It is likely, however, that treatment of $\mathrm{PC} 12$ cells with DEX or NGF results in a cascade of effects. Two of the many possible end points of these cascades could be alterations of enzymatic or ionic current activity. It would be of interest to determine if the specific activity of these enzymes is increased in clone $B$.

Our results show that undifferentiated PC1 2 cells can express both high- and low-threshold-type $\mathrm{Ca}$ currents. This is true for both the untreated population of PC12 cells and of the subclone, clone $\mathrm{B}$. The existence of more than one type of Ca current in PC1 2 cells had been suggested in the work of Takahashi et al. (1985) and Kongsamut and Miller (1986). The presence of T-type Ca current differs from the results of Streit and Lux (1987), who did not observe a T-type Ca current in PC1 2 cells, although high-threshold Ca currents were recorded. Streit and Lux observed, however, that these Ca currents inactivated more rapidly after the application of NGF. These differences may be caused by experimental or inherent differences between the clonal PC1 2 cell lines used. We have found that the fraction of cells exhibiting the low-threshold $\mathrm{T}$-type $\mathrm{Ca}^{2+}$ current and the density of this current increased in response to NGF and DEX, with confluence, and in clone B. Plummer et al. (1989) have investigated changes in high-threshold $\mathrm{Ca}$ channels in $\mathrm{PC} 12$ cells in response to NGF and suggested that NGF causes an increase in the N-type Ca channel. Our work does not address differential changes in the high-threshold currents, as they were not distinguished from each other.

Because the T-type Ca currents were observed in at least some cells in the untreated and DEX-and NGF-treated groups, it is clear that the presence of the T-type current is not prerequisite for any one differentiated state. While some differentiated NGFtreated cells only had high-threshold current, some perfectly spherical untreated cells expressed very robust T-type currents. Although DEX-treated PC1 2 cells are considered similar to adrenal chromaffin cells, DEX-treated PC12 cells express both T-type and high-threshold currents, whereas chromaffin cells do not appear to have T-type currents (Fenwick et al., 1982; Hoshi et al., 1984). Thus, while it is possible that different voltagedependent currents have different cellular functions, the relative contributions of T-type, high-threshold $\mathrm{Ca}^{2+}$, and $\mathrm{Na}^{+}$channels to cellular physiology may also be important to cellular differentiation.

\section{References}

Allen, J. M., A. S. Tishler, Y. C. Lee, and S. R. Bloom (1984) Ncuropeptide Y (NPY) in PC12 pheochromocytoma cultures: Responses to dexamethasone and nerve growth factor. Neurosci. Lett. 46: 291296.

Bethea, C. L., and S. L. Kozak (1984) Effect of extracellular matrix on PCl 2 cell shape and dopamine processing. Mol. Cell Endocrinol. 37: 319-329.

Bethea, C. L., and S. L. Kozak (1985) Further characterization of substratum influence on $\mathrm{PC} 12$ cell shape and dopamine processing. Mol. Cell Endocrinol. 42: 59-72.

Chen, C., M. J. Corbley, T. M. Roberts, and P. Hess (1988) Voltagesensitive calcium channels in normal and transformed 3T3 fibroblasts. Science 239: 1024-1026.

Dichter, M. A., A. S. Tishler, and L. A. Greene (1977) Nerve growth factor-induced increase in electrical excitability and acetylcholine sensitivity of a rat pheochromocytoma cell line. Nature 268: 501-504.

Doherty, P., D. A. Mann, and F. Walsh (1987) Cell-cell interactions modulate the responsiveness of $\mathrm{PC} 12$ cells to nerve growth factor. Development 101: 605-615.

Edgar, D. H., and H. Thoenen (1978) Selective enzyme induction in a nerve growth factor-responsive pheochromocytoma cell line (PC12). Brain Res. 154: 186-190.

Fenwick, E. M., A. Marty, and E. Neher (1982) Sodium and calcium channels in bovine chromaffin cells. J. Physiol. (Lond.) 331: 599635.

Goodman, R., C. Chandler, and H. R. Herschman (1979) Pheochromocytoma cell lines as models of neuronal differentiation. In Hormones and Cell Culture, G. H. Sato and R. Ross, eds., pp. 653-669, Cold Spring Harbor Laboratory, Cold Spring Harbor, New York.

Greene, L. A., and G. Rein (1977) Synthesis, storage and release of acetylcholine by a noradrenergic pheochromocytoma cell line. Nature 268: 349-351.

Greene, L. A., and A.S. Tishler (1976) Establishment of a noradenergic clonal line of rat adrenal pheochromocytoma cells which respond to nerve growth factor. Proc. Natl. Acad. Science USA 73: 2424-2428.

Grothe, C., H.-D. Hofmann, A. A. J. Verhoftad, and K. Unsicker (1985) Nerve growth factor and dexamethasone specify the catecholaminergic phenotype of cultured rat chromaffin cells: Dependence on developmental stages. Dev. Brain Res. 21: 125-132.

Hamill, O. P., A. Marty, E. Neher, B. Sakmann, and F. J. Sigworth (1981) Improved patch-clamp technique for high resolution current recordings from cells and cell-free membrane patches. Pfluegers Arch. 391: 85-100.

Harris, K. M., S. Kongsamut, and R. J. Miller (1986) Protein kinase $\mathrm{C}$ mediated regulation of calcium channels in PC-12 pheochromocytoma cells. Biophys. Biochem. Res. Comm. 134: 1298-1305.

Hirning, L. D., A. P. Fox, E. W. McCleskey, B. M. Olivera, S. A. Thayer, R. J. Miller, and R. W. Tsien (1988) Dominant role of $\mathrm{N}$-type $\mathrm{Ca}^{2+}$ channels in evoked release of norepinephrine from sympathetic neurons. Science 239: 57-61.

Hoshi, T., and R. W. Aldrich (1988a) Voltage-dependent $\mathrm{K}^{+}$currents and underlying single $\mathrm{K}^{+}$channels in pheochromocytoma cells. $\mathrm{J}$. Gen. Physiol. 91: 73-106.

Hoshi, T., and R. W. Aldrich (1988b) Gating kinetics of four classes of voltage-dependent $\mathrm{K}^{+}$channels in pheochromocytoma cells. J. Gen. Physiol. 91: 107-131.

Hoshi, T., J. Rothlein, and S. J. Smith (1984) Facilitation of $\mathrm{Ca}^{2+}-$ currents in bovine adrenal chromaffin cells. Proc. Natl. Acad. Science USA 81: 5871-5875.

Kater, S. B., M. P. Mattson, C. Cohan, and J. Connor (1988) Calcium regulation of the neuronal growth cone. Trends Neurosci. 11:315321.

Kongsamut, S., and R. J. Miller (1986) Nerve growth factor modulates the drug sensitivity of neurotransmitter release from PC-12 cells. Proc. Natl. Acad. Sci. USA 83: 2243-2247.

Lagenaur, C., and V. Lemmon (1987) An Ll-like molecule, the 8D9 antigen, is a potential substrate for neurite extension. Proc. Natl. Acad. Sci. USA 84: 7753-7757.

Lillien, L. E., and P. Claude (1985) Nerve growth factor and glucocorticoids regulate phenotypic expression in cultured chromaffin cells from adult Rhesus monkeys. Exp. Cell Res. 161: 255-268.

Lin, S. S., and I. B. Levitan (1988) Concanavalin A alters synaptic specificity between cultured Aplysia neurons. Science 237: 648-649.

Lucas, C. A., D. Edgar, and H. Thoenen (1979) Regulation of tyrosine hydroxylase and choline acetyletransferase activities by cell density in $\mathrm{PC} 12$ rat pheochromocytoma clonal cell line. Exp. Cell Res. 121: 79-86.

Lucas, C. A., A. Czlonkowska, and G. W. Kreutzberg (1980) Regulation of acetylcholinesterase by nerve growth factor in the pheochromocytoma PC12 cell line. Neurosci. Lett. 18: 333-337. 
Mandel, G., S. S. Cooperman, R. A. Maue, R. H. Goodman, and P. Brehm (1988) Selective induction of brain type II Na+ channels by nerve growth factor. Proc. Natl. Acad. Sci. USA 85: 924-928.

Miller, R. J. (1988) Calcium signalling in neurons. Trends Neurosci. 11: 415-419.

Otten, U., and M. Towbin (1980) Permissive action of glucocorticoids in induction of tyrosine hydroxylase by nerve growth factor in a pheochromocytoma cell line. Brain Res. 193: 304-308.

Plummer, M. R., D. E. Logothetis, and P. Hess (1989) Elementary properties and modulation of calcium channels in mammalian peripheral neurons. Neuron 2: 1447-1463.

Rane, S. G., G. G. Holz IV, and K. Dunlap (1987) Dihydropyridine inhibition of neuronal calcium current and substance $P$ release. Pfluegers Arch. 409: 361-366.

Reiger, F., M. L. Shelanski, and L. A. Greene (1980) The effect of nerve growth factor on acetylcholinesterase and its multiple forms in cultures of rat PC1 2 pheochromocytoma cells: Increased total specific activity and appearance of the $16 \mathrm{~S}$ molecular form. Dev. Biol. 76 : 238-243.

Rudy, B., and J. D. Pollock (1988) Long-term regulation of potassium channels in PC12 pheochromocytoma cells by nerve growth factor. Soc. Neurosci. Abstr. 14: 141.

Rudy, B., B. Kirschenbaum, and L. A. Greene (1982) Nerve growth factor-induced increase in saxitoxin binding to rat PC12 pheochromocytoma cells. J. Neurosci. 2: 1405-1411.

Schubert, D., M. LaCorbiere, F. G. Klier, and J. H. Steinbach (1980) The modulation of neurotransmitter synthesis by steroid hormones and insulin. Brain Res. 190:67-79.

Spitzer, N. C. (1985) The control of development of neuronal excitability. In Molecular Bases of Neural Development, G. M. Edelman, W. E. Gall, and W. M. Cowan, eds., pp. 67-88, Rockefeller U.P., New York.

Streit, J., and H. D. Lux (1987) Voltage dependent calcium currents in PC12 growth cones and cells during NGF-induced cell growth. Pfluegers Arch. 408: 634-641.
Takahashi, M., H. Tsuku, and H. Hatanaka (1985) Neuronal differentiation of $\mathrm{Ca}^{2+}$ channel by nerve growth factor. Brain Res. 341: 381-384.

Tishler, A. S., Y. C. Lee, V. W. Slayton, and S. R. Bloom (1982a) Content and release of neurotensin in $\mathrm{PC} 12$ pheochromocytoma cell cultures: Modulation by dexamethasone and nerve growth factor. Reg. Peptide 3: 415-421.

Tishler, A. S., R. L. Perlman, G. Nunnemacher, G. M. Morse, R. A. DeLellis, H. J. Wolfe, and B. E. Sheard (1982b) Long-term effects of dexamethasone and nerve growth factor on adrenal medullary cells cultured from young adult rats. Cell Tissue Res. 225: 525-542.

Tishler, A. S., R. L. Perlman, G. M. Morse, and B. E. Sheard (1983) Glucocorticoids increase catecholamine synthesis and storage in PC12 pheochromocytoma cell cultures. J. Neurochem. 40:364-370.

Tishler, A. S., Y. C. Lee, R. L. Perlman, D. Costopoulos, V. W. Slayton, and S. R. Bloom (1984) Production of "ectopic" vasoactive intestinal peptide-like and neurotensin-like immunoreactivity in human pheochromocytoma cell cultures. J. Neurosci. 4: 1398-1404.

Tishler, A. S., Y. C. Lee, R. L. Perlman, D. Costopoulos, V. W. Slayton, W. J. Jason, and S. R. Bloom (1986) Cooperative regulation of neurotensin content in PC12 pheochromocytoma cell cultures: Effects of nerve growth factors, dexamethasone, and activators of adenylate cyclasc. J. Neurosci. 6: 1719-1725.

Tomaselli, K. J., L. F. Reichardt, and J. L. Bixby (1986) Distinct molecular interactions mediate neuronal process outgrowth on nonneuronal cell surfaces and extracellular matrices. J. Cell Biol. 103: 2659-2672.

Tsien, R. W., A. P. Fox, P. Hess, E. W. McCleskey, B. Nilius, M. C. Nowycky, and R. L. Rosenberg (1987) Multiple types of calcium channel in excitable cells. In Proteins of Excitable Membranes, B. Hille and D. M. Fambrough, eds., pp. 167-187, Wiley, New York.

Unsicker, K., B. Krisch, U. Otten, and H. Thoenen (1978) Nerve growth factor-induced fiber outgrowth from isolated rat adrenal chromaffin cells: Impairment by glucocorticoids. Proc. Natl. Acad. Sci. USA 75: 3498-3502. 